DOI https://doi.org/10.30525/978-9934-26-004-9-91

\title{
CURRENT PROBLEMS OF ACTIVITIES OF CULTURAL INSTITUTIONS IN A DECENTRALIZED ENVIRONMENT
}

\author{
Mytnyk A. A. \\ Candidate of Sciences in Public Administration, \\ Associate Professor at the Department of Law Sciences \\ Kremenchuk Mykhailo Ostrohradskyi National University \\ Kremenchuk, Poltava region, Ukraine \\ Nosa I. \\ $3^{\text {rd }}$ year Student \\ Kremenchuk Mykhailo Ostrohradskyi National University \\ Kremenchuk, Poltava region, Ukraine
}

In the current context of Ukraine's policy of decentralization, there are questions about the activities of cultural institutions in rural areas. Ukrainian legislation contains a set of standards and regulations governing social relations in the field of sociocultural activities. These standards form the legal basis for cultural activities and define the principles, objectives and mechanisms for the implementation of State policy. For a broader understanding of the state of sociocultural activity in Ukraine, especially its existence in a decentralized environment, it is necessary to pay attention to the creative industries, because their stimulation is one of the key trends in both cultural and economic policy of developed countries.

One of the constitutional freedoms of Ukrainian citizens is «Freedom of literary, artistic, scientific and technical creativity, protection of intellectual property, copyrights, moral and material interests arising from intellectual activity in this field» [1]. The process of state administration in culture sector is based on this provision.

One of the key problems for amalgamated territorial community (ATC) is the deterioration of socio-cultural infrastructure and low energy efficiency of cultural institutions, which makes their maintenance too costly. During the decentralization, the responsibility for maintaining these institutions fell to the amalgamated community (ATC). No mechanisms of State support in this sense were provided.

Moreover, the culture has always been funded residually. And now funding continues to be made available to address the immediate needs of communities. Subventions received by communities as part of the reform were aimed at road mending, renovating municipal equipment, water suppling, and upgrading. As a result, it is impossible to maintain cultural institutions and 
provide quality cultural services to the population in less well-off communities. This may result in depressed territories being left without cultural facilities, cultural programs and projects.

Another problem that exists in villages, towns and small towns is the socalled «staff shortage». Low wages and lack of professional prospects in rural areas don't help involvement of experts to work for positions in the field of culture. In the more capable ATCs, as well as in the communities that have become the centers of the community, there is often at least a team of the director, the artistic director, the circle leaders who organize the cultural life in the community. But in small villages, in houses of culture, the enthusiasm of only one person who has worked in this position all his life is still held. This person is at the same time a director, artistic director, head of all circles, and sometimes a technical worker. According to R. Yu. Mylian, increased attention to solving problems of the sociocultural development of rural settlements will contribute to the preservation and development of cultural institutions in rural areas, prevent the outflow of the working and most educated population, especially young people, and will eventually strengthen the sustainable development potential of Ukraine as a whole. The organization and holding of mass cultural events in rural areas is an effective means of strengthening the competitiveness of rural areas, enhances the development of cultural interregional and cross-border cooperation, event-tourism and has a positive impact on the branding of rural settlements as tourist attractions [2].

Conclusion. To address the above issues, is invited to identify an approach whereby a State, acting by the Culture Ministry, will develop standards for the minimum volume and quality of cultural services, compliance with which will be mandatory for local governments in communities. This may occur by defining and establishing a set of basic services guaranteed by the State and financed from the State budget. For the normal functioning of State culture, it is necessary to establish a new concept of these institutions activities in the ATC, to provide for tax exemption by legal acts and to clearly define the types of services provided by cultural activity.

Thus, the principles of the State cultural policy enshrined in the law are lagging behind and require some adjustment, and the priorities of State policy require fundamental revision, taking into account the social and political changes in Ukraine and global trends in cultural development.

\section{References:}

1. Конституція України : Закон України від 28 червня 1996 p. URL: https://zakon.rada.gov.ua/laws/show/254к/96-вр\#Text (дата звернення 01.09.2020 p.)

2. Милян Р. Ю. Проблеми та пріоритети соціокультурного розвитку сільських територій. Сои. - ек. проблеми сучас. періоду Украӥни. 2013. Вип. 6 (104). С. 326 - 331. 